\title{
原著
}

\section{Expression of Cannabinoid Receptor GPR55 in Human Gingival Fibroblasts and Anti-inflammatory Effects of Cannabidiol via GPR55}

\author{
Saki Mishiro, Hiroko Igarashi-Takeuchi and Yukihiro Numabe
}

Department of Periodontology, The Nippon Dental University, School of Life Dentistry at Tokyo

(Received: November 20, 2020 Accepted: January 5, 2021)

\begin{abstract}
Cannabidiol (CBD) in cannabis has an anti-inflammatory effect, and its receptor, G proteincoupled receptor 55 (GPR55), has been suggested to be involved in the regulation of inflammation. Here, we investigated GPR55 expression in human gingival fibroblasts (HGFs) and anti-inflammatory effects of CBD via GPR55.

GPR55 expression and localization were confirmed in control, LPS-stimulated (LPS), CBD-treated and LPS-stimulated (CBD + LPS), and CBD-treated (CBD) groups. We also compared interleukin (IL)-6 and IL8 protein production in each group.

GPR55 expression levels were significantly reduced in the LPS and CBD + LPS groups $(p<0.05)$ compared to control and CBD groups, and GPR55 protein was found diffusely in the cytoplasm of HGFs in all groups. In addition, IL-6 and IL-8 production was significantly reduced in non-knockdown HGFs in the CBD + LPS group compared to the LPS group $(p<0.05)$. By contrast, in GPR55-knockdown HGFs, there was a significant increase in IL- 6 and IL- 8 production in the LPS and CBD + LPS groups compared with the control groups $(p<0.05$ ), but there was no significant difference in IL-6 and IL-8 production in GPR 55-knockdown HGFs between the LPS and CBD + LPS groups.

In this study, we confirmed the homeostatic expression of GPR55 in HGFs and its tendency to decrease in expression during inflammation. It was also shown that part of an anti-inflammatory effect by CBD may be mediated by GPR55.
\end{abstract}

Nihon Shishubyo Gakkai Kaishi (J Jpn Soc Periodontol) 63 (1): 11-23, 2021

Key words: Cannabidiol, G protein-coupled receptor 55, Anti-inflammatory effects, Cytokines, Human gingival fibroblasts

\section{Introduction}

Periodontitis is an inflammatory disease of the periodontal tissue that is caused by dental plaque ${ }^{1)}$. As the plaque matures, periodontal pathogens predominate. Periodontopathic bacteria are Gram-negative and their outer membrane contains lipopolysaccharide

Corresponding author: Hiroko Igarashi-Takeuchi Department of Periodontology, The Nippon Dental University, School of Life Dentistry at Tokyo 1-9-20 Fujimi, Chiyoda-ku, Tokyo-to 102-8159, Japan E-mail: hiroko.p0324@gmail.com doi : 10.2329/perio.63.11
(LPS). LPS binds to Toll-like receptor 4 (TLR4) on the surface of periodontal tissue cells, including human gingival fibroblasts (HGFs), which constitute the connective tissue of the gingiva, and secretes proinflammatory cytokines through signal transduction 2,3$)$. In particular, interleukin (IL)-6 regulates the differentiation and proliferation of immune cells and also exacerbates periodontal disease by inducing bone resorption ${ }^{4)}$. In addition, IL-8 induces the migration of inflammatory cells and osteoclasts in periodontal disease, and it is therefore thought to be involved in the destruction of periodontal tissues ${ }^{5}$ ). Mechanical plaque control for the removal of dental plaque, which is the source of infection, is an important part of periodontal treatment ${ }^{6}$ ). However, due to the limited effectiveness of mechanical plaque control7), chemical plaque con- 
trol is being sought as an adjunctive therapy ${ }^{8)}$. One of these adjunctive therapies is host modulation therapy, which is used to inhibit the secretion of inflammatory cytokines to prevent destruction of periodontal tissue $^{9)}$. In this study, we focused on cannabidiol (CBD), a major component of cannabinoids in cannabis that has anti-inflammatory properties.

CBD has no psychoactivity, unlike the other components of cannabis ${ }^{10)}$, and has been widely studied for medical applications due to its beneficial antiepileptic effect11), pain relief ability ${ }^{12)}$, anticancer activity ${ }^{13)}$, and bone growth promoting activity 14 ). CBD is a terpene phenol with the molecular formula $\mathrm{C}_{21} \mathrm{H}_{30} \mathrm{O}_{2}$ and a molecular weight of $314.47 \mathrm{~g} / \mathrm{mol}$. It is insoluble in water and soluble in organic solvents ${ }^{15}$ ). It has been clinically applied as a drug and is approved in some countries for advanced cancer pain and neuropathic pain relief and as epilepsy treatment 16 ). In addition, the efficacy of CBD in the treatment of rheumatoid arthritis ${ }^{17}$ ) has led to the recent development of antiinflammatory effects that are expected to be clinically applied 18,19$)$.

Two types of cannabinoid receptors, cannabinoid receptor 1 and 2 (CB1 and CB2), have been identified as receptors for $\mathrm{CBD}$ containing cannabinoids, which are $\mathrm{G}$ protein-coupled receptors (GPCRs) with seven transmembrane domains ${ }^{20)}$. CB1 receptors are primarily distributed in the central nervous system and mediate most psychoactive effects, such as pain relief and muscle spasm relief through activation ${ }^{21)}$. CB2 receptors are mainly expressed on peripheral and immune cells and mediate immunosuppressive effects such as antiinflammatory and analgesic effects ${ }^{22}$. However, accumulating evidence from many studies has suggested the existence of new cannabinoid receptors that are distinct from $\mathrm{CB} 1$ and $\mathrm{CB} 2$ receptors.

In the mid-2000s, the orphan G protein-coupled receptor 55 (GPR55) was presented as a major candidate for a new cannabinoid receptor ${ }^{23)}$. High GPR55 expression has been reported in malignant breast cancer cells and osteoclasts24,25). Therefore, there have been many studies on GPR55 and its therapeutics as targets for the treatment of cancer and bone metabolic diseases. Additionally, the relationship between GPR55 and inflammation has been reported ${ }^{18)}$. For example, GPR55, when activated by the endogenous agonist lysophosphatidylinositol (LPI), is thought to play a role in exacerbating inflammation by activating transcriptional regulators such as nuclear factor-kappa B (NF$\kappa \mathrm{B})$ through the activation of ERK and p $38 \mathrm{MAP}$ kinases, thus promoting the production of proinflammatory cytokines 26,27). Other reports showed increased GPR55 expression in intestinal tissues of rats with LPS-induced intestinal inflammation and suggested that CBD was effective in suppressing enteritis ${ }^{28)}$. Furthermore, it has been reported that GPR55 is highly expressed in monocytes and natural killer cells, and GPR55 activation promotes the production of proinflammatory cytokines, which are conversely inhibited by CBD 29). Thus, GPR55 has been suggested to be associated with inflammation in various tissues, but little has been clarified on its role in periodontal tissue. Because CB1 and CB2 expression in periodontal tissues and their association with inflammation have been reported 30,31 ), it is likely that GPR55 is similarly relevant. The anti-inflammatory effect of $\mathrm{CBD}$ on rats induced by experimental periodontitis has been reported 32 ), but there are few studies on $\mathrm{CBD}$ and periodontal tissues. Furthermore, the detailed mechanism underlying the anti-inflammatory effect of CBD and its association with GPR55 remain unclear. Therefore, we hypothesized that GPR55 is expressed in periodontal tissue and is associated with inflammation and CBD has an anti-inflammatory effect on periodontal tissue by acting as an antagonist of GPR55.

In the present study, we first confirmed the presence of GPR55 expression in HGFs and then observed changes in GPR55 expression in HGFs of inflammation induced by LPS stimulation. In addition, the relationship between anti-inflammatory effects of CBD and GPR55 was also investigated using HGFs with knockdown of GPR55 gene expression.

\section{Materials and Methods}

\section{1, Cell culture}

Immortalized HGFs (Applied Biological Materials Inc., BC, Canada) were cultured in Dulbecco's Modified Eagle Medium: Nutrient Mixture F-12 (Thermo Fisher Scientific, Waltham, MA, USA) supplemented with 10 $\mu \mathrm{L} / \mathrm{mL}$ Antibiotic-Antimycotic (Thermo Fisher Scientific) and $10 \%$ fetal bovine serum (BioWest, Nuaillé, France) at $37^{\circ} \mathrm{C}$ in $5 \% \mathrm{CO}_{2}$ atmosphere. Cells between passages 3 and 7 were used in experiments.

\section{2, Effect of CBD and LPS on HGF cell proliferation}

Effects of CBD (Sigma-Aldrich, St. Louis, MO, USA) and LPS (from Escherichia coli O 111: B4, SigmaAldrich) on HGF cell proliferation were assessed by 
MTT assay. Individual wells of 96-well microtiter tissue culture plates were seeded with $5.0 \times 10^{3}$ cells in $100 \mu \mathrm{L}$ of complete medium. Cells were incubated overnight at $37^{\circ} \mathrm{C}$ in $5 \% \mathrm{CO}_{2}$ atmosphere, the medium was replaced with reagent added medium adjusted to each concentration for 4 days. CBD concentrations evaluated were $0,0.005,0.05,0.5,5$, and $10 \mu \mathrm{M}$, and LPS concentrations used were $0,0.01,0.1,1$, and $10 \mu \mathrm{g}$ / $\mathrm{mL}$. After 4 hours of incubation with the Cell Counting Kit-8 WST-8 (DOJINDO, Kumamoto, Japan), cell proliferation was measured using a spectrophotometer (SH9000, Corona Electric, Hitachinaka, Japan) at $450 \mathrm{~nm}$ absorbance. Results are presented as optical density at $450 \mathrm{~nm}$.

\section{3, Experimental design}

To investigate GPR55, CB1, and CB2 expression in HGFs, variations in expression upon LPS stimulation, and anti-inflammatory effects of $\mathrm{CBD}$, the following conditions were established. Untreated cells were used as the control group, and cells stimulated by 0.1 $\mu \mathrm{g} / \mathrm{mL}$ LPS for $24 \mathrm{~h}$ were included as the LPS group. Cells pre-treated with $0.5 \mu \mathrm{M}$ CBD for $2 \mathrm{~h}$ and then cultured in $0.1 \mu \mathrm{g} / \mathrm{mL}$ LPS-supplemented medium for $24 \mathrm{~h}$ were used as the CBD + LPS group, and cells pretreated with $\mathrm{CBD}$ for $2 \mathrm{~h}$ and then cultured in LPSfree medium for $24 \mathrm{~h}$ were included as the CBD group.

\section{RNA extraction and quantitative reverse transcription-polymerase chain reaction ( $q R T$ - PCR)}

Cells were seeded into 6 -well plates at $2.5 \times 10^{5}$ cells $/ \mathrm{mL}$, incubated for $24 \mathrm{~h}$, and then cultured for 24 $\mathrm{h}$ under the four conditions described above. Total RNA was extracted from HGFs using the Maxwell ${ }^{\circledR}$ RSC simplyRNA Cells Kit (Promega, Madison, WI, USA) according to the manufacturer's instructions. cDNA was then synthesized from total RNA using SuperScript ${ }^{\circledR}$ VILO Master Mix (Invitrogen, Thermo Fisher Scientific). $\beta$-Actin was used as the internal standard. Primer sequences used to detect each gene are as follows: CB1 (Hs01038522, Applied Biosystems, Thermo Fisher Scientific), CB2 (Hs00361490, Applied Biosystems, Thermo Fisher Scientific), GPR55 (Hs 00271662, Applied Biosystems, Thermo Fisher Scientific), and B-Actin (NM_001101.2, Applied Biosystems, Thermo Fisher Scientific). Quantitative real-time PCR was performed using gene-specific primers and TaqMan Fast Advanced Master Mix (Invitrogen, Thermo Fisher Scientific), cDNA template (corre- sponding to $10 \mathrm{ng} / \mu \mathrm{L} \mathrm{cDNA}$ ), primers, and probes in a final reaction volume of $20 \mu \mathrm{L}$ on a real-time PCR system. Cycling conditions for each gene were as follows: $95^{\circ} \mathrm{C}$ for $20 \mathrm{~min}, 40 \mathrm{cycles}$ of $1 \mathrm{~min}$ at $95^{\circ} \mathrm{C}$, and $60^{\circ} \mathrm{C}$ for $20 \mathrm{~min}$. To compare gene expression levels between different samples, relative gene expression levels were calculated by the $\Delta \Delta \mathrm{CT}$ method using StepOnePlus software (Applied Biosystems, Thermo Fisher Scientific).

\section{5, Western blotting analysis}

Cells were cultured under the same conditions as described above for qRT-PCR. Cells were then rinsed with cold PBS and divided into cytoplasmic and nuclear fractions. Samples were then electrophoresed in 10\% resolving sodium dodecyl sulfate-polyacrylamide gels and transferred to polyvinylidene difluoride membranes. Then, membranes were reacted with specific antibodies against each target and internal standard and detected by the chemiluminescence method (ECL select, GE Healthcare, Chicago, IL, USA). $\beta$-Actin was used as the internal standard for cytoplasmic fractions and histone was included as the internal standard for nuclear fractions. Membranes were incubated at $4^{\circ} \mathrm{C}$ overnight with primary rabbit anti-GPR55 (ab3561, Abcam, Cambridge, UK), CB1 (ab23703, Abcam), and CB2 (ab3561, Abcam) serum. For internal standard, monoclonal anti- $\beta$-actin antibody produced in mouse clone (A 5441, Sigma-Aldrich) and monoclonal antihistone antibody (Histone H3 antibody, 9715S, Cell Signaling, Beverly, MA, USA) were used. Rabbit IgG HRP (NA934, GE Healthcare) and mouse IgG HRP (NXA 931, GE Healthcare) were used as secondary antibodies. The ratio of protein expression to internal control was calculated using CS Analyzer Image Analysis Software (Atto Corporation, Tokyo, Japan).

\section{Immunofluorescence assay}

HGFs were seeded onto 8-well culture slides at 1.0 $\times 10^{4} \mathrm{cells} / \mathrm{mL}$ and incubated for $24 \mathrm{~h}$, and then cells were cultured under the same conditions as described above for qRT-PCR. Cells were washed with $0.01 \mathrm{M}$ PBS and fixed in 4\% paraformaldehyde for $30 \mathrm{~min}$. Cells were permeabilized for $20 \mathrm{~min}$ in $0.1 \%$ Triton X100 in PBS, then treated with blocking buffer (1\% BSA in PBS) for $1 \mathrm{~h}$. The same primary antibodies used in western blotting analyses were used for staining of each receptor and the nucleus (DAPI stain), and cells were incubated at $4^{\circ} \mathrm{C}$ overnight. Cells were then washed with PBS and incubated with goat anti-rabbit 
IgG $(\mathrm{H}+\mathrm{L})$ Cross-Adsorbed Secondary Antibody Alexa Fluor 488 (A11008, Thermo Fisher Scientific) for 2 h. Thereafter, cells were contrast-stained by DAPI and sealed (Vector Laboratories, Burlingame, CA, US). Stained samples were evaluated under a confocal laser scanning microscope (LSM700, Carl Zeiss MicroImaging $\mathrm{GmbH}$, Oberkochen, Germany).

\section{7, Transfection with GPR55 siRNA}

To assess the presence of a GPR55-dependent inflammatory response, human GPR55 siRNA (Dharmacon, Horizon Discovery, Lafayette, CO, USA) and negative control siRNA (Dharmacon, Horizon Discovery) were used for transfection. Cells were transfected with $50 \mathrm{nM}$ siRNA using DharmaFECT 1 Transfection Reagent (Dharmacon, Horizon Discovery) according to the manufacturer's instructions. Cells collected at 24-h post-transfection were used for enzyme-linked immunosorbent assays (ELISAs).

\section{8, ELISAS}

To evaluate the inhibitory effect of CBD on proinflammatory cytokine secretion, transfected HGFs were cultured in 24 -well plates at $3.0 \times 10^{4}$ cells $/ \mathrm{mL}$ and culture supernatants were collected. IL- 6 and IL- 8 protein expression in supernatants was quantified by ELISA (Quantikine ELISA Human IL-6, Human CXCL 8/IL-8, R\&D Systems, Minneapolis, MN, USA) and determined by a spectrophotometer (SH-9000, Corona Electric) used to measure the absorbance at $450 \mathrm{~nm}$ (reference wavelength of $570 \mathrm{~nm}$ ). The concentration of each inflammatory cytokine was calculated according to a standard curve.

\section{9, Statistical analysis}

All data are presented as mean \pm standard deviation (SD) from five independent experiments. The normality of the distribution in measured data was confirmed by the Kolmogorov-Smirnov test. Subsequently, for qRT-PCR and Western blot data, the Tukey comparison test or the Games-Howell test was used as a oneway ANOVA and post-hoc test for comparisons between the four groups. Statistically significant differences between groups in the ELISA data were obtained using the Kruskal-Wallis test and the SteelDwass test as data showing a non-normal distribution. All statistical processing was performed using SPSS version 25 (IBM, Chicago, IL, USA). $P$ values less than $<0.05$ were considered statistically significant.

\section{Results}

\section{Effects of CBD and LPS on HGF cell proliferation}

To determine CBD and LPS concentrations used in the experiments, the concentration-dependent effects of each reagent on HGF cell proliferation were analyzed. CBD concentrations below $0.05 \mu \mathrm{M}$ had no significant effect on cell proliferation after 1-4 days of exposure. Compared to the control group, cell proliferation in 5 and $10 \mu \mathrm{M}$ CBD groups was significantly reduced after day $2(p<0.05)$. After 4 days, there was a significant increase in the $0.5 \mu \mathrm{M} \mathrm{CBD}$ group compared to the control group $(p<0.01) \quad$ (Figure $1 \mathrm{~A})$. At LPS concentrations of 0.01 and $10 \mu \mathrm{g} / \mathrm{mL}$, HGF cell proliferation was similar to that observed in the control group (Figure 1B). There was a tendency for HGF cell proliferation to decrease at LPS concentrations of $0.1 \mu \mathrm{g} / \mathrm{mL}$ and $1 \mu \mathrm{g} / \mathrm{mL}$ compared to the control group on days 3 and 4 , but this decrease was not significant. Therefore, in subsequent experiments, the optimal concentration of $\mathrm{CBD}$ was determined to be 0.5 $\mu \mathrm{M}$. The optimal concentration of LPS was determined to be $0.1 \mu \mathrm{g} / \mathrm{mL}$, which has the highest production of pro-inflammatory cytokines in the range of 0-10 $\mu \mathrm{g} / \mathrm{mL}$.

\section{2, GPR55, CB1, and CB2 mRNA expression levels}

To assess the effect of LPS on mRNA expression of cannabinoid receptors GPR55, CB1, and CB2, changes in mRNA expression in HGFs at 1, 4, 12, and $24 \mathrm{~h}$ after $0.1 \mu \mathrm{g} / \mathrm{mL}$ LPS stimulation were analyzed using qRTPCR. At $1 \mathrm{~h}$ after LPS stimulation, there was no significant difference between groups (Figure 2). In the LPS and CBD + LPS groups, there was a trend toward decreased GPR55 mRNA expression at 4-12 $\mathrm{h}$ after LPS stimulation, with a significant decrease in expression in both groups at $24 \mathrm{~h}(p<0.05)$. CB1 and CB2 mRNA expression was not observed in any group from the start of LPS stimulation to $24 \mathrm{~h}$ after treatment (data not shown).

\section{3, GPR55, CB1, and CB2 protein expression}

GPR55, CB1, and CB2 protein expression levels in each group were analyzed by western blotting $24 \mathrm{~h}$ after LPS stimulation. GPR55 protein was detected in the cytoplasmic fraction but not in the nuclear fraction. Furthermore, GPR55 protein expression in cytoplasmic fractions showed a significant downward trend in the LPS and CBD + LPS groups compared to 
A

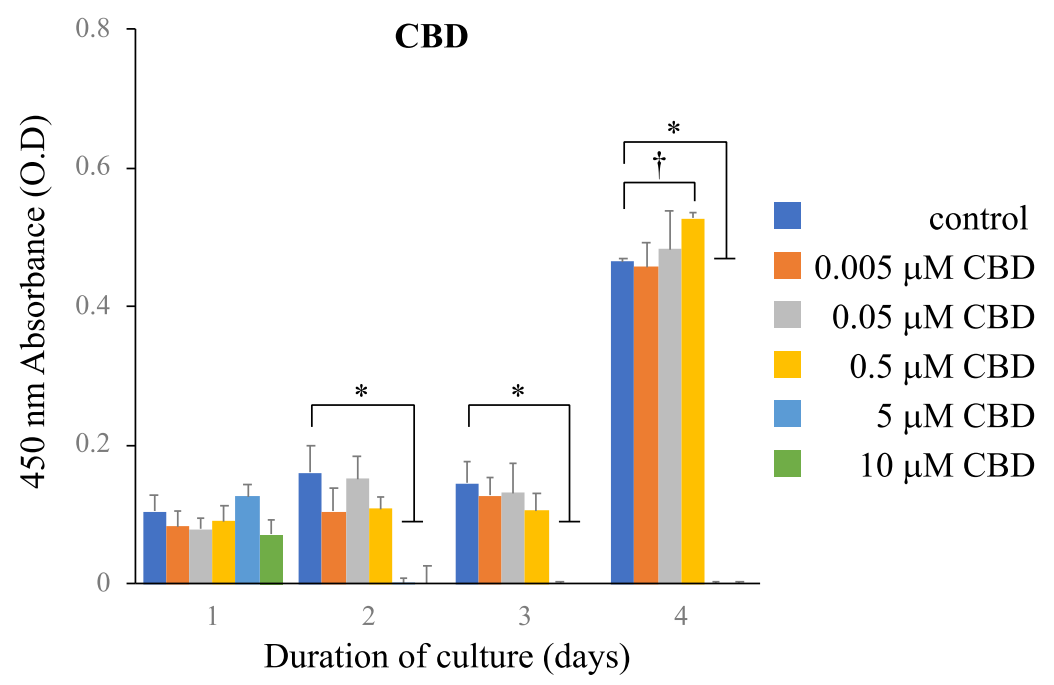

B

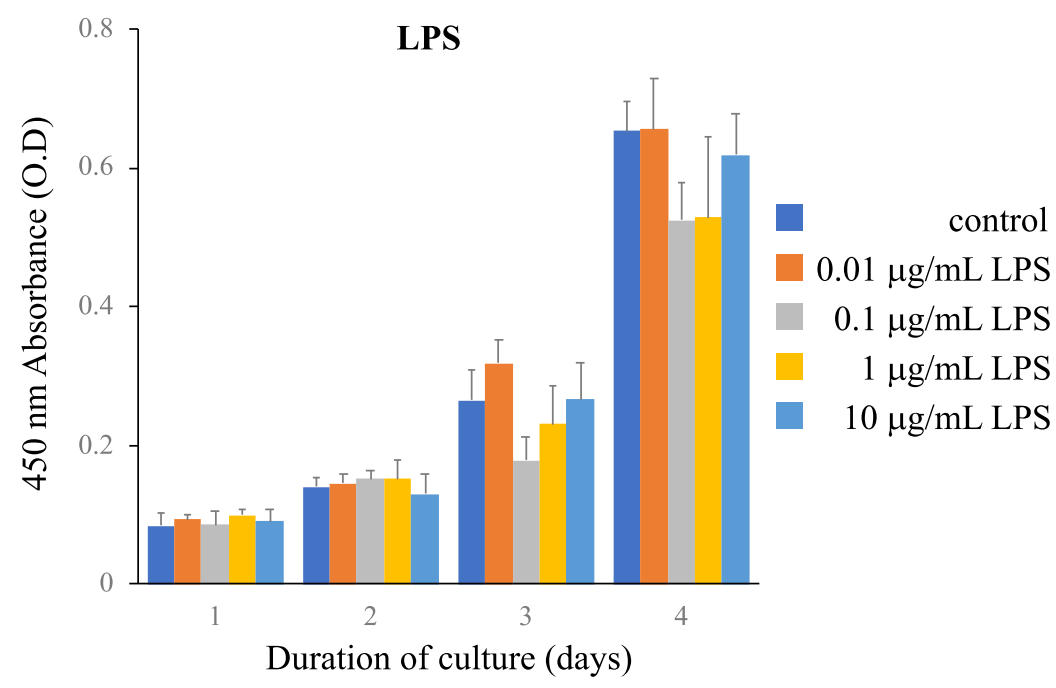

Figure 1 Effects of A) CBD and B) LPS on HGF viability. Data represent mean \pm SD from five independent experiments. ${ }^{*} p<0.01,{ }^{\dagger} p<0.05$, Tukey's comparison test.

the control group $(p<0.05)$ (Figure 3$)$. The CBD group showed the same expression trend as the control group. $\mathrm{CB} 1$ and $\mathrm{CB} 2$ protein expression was not observed in any group (data not shown).

\section{4, Localization of GPR55, CB1, and CB2 proteins in HGFs}

The localization of each cannabinoid receptor in HGFs was analyzed by fluorescence immunostaining. In the control group, GPR55 expression was observed diffusely in the cytoplasm (Figure 4A). In the LPS, $\mathrm{CBD}+\mathrm{LPS}$, and CBD groups, GPR55 was also expressed in the cytoplasm as well as in the control group. CB1 was also expressed throughout HGFs in all conditions tested (Figure 4B). By contrast, CB2 expression was not observed (Figure 4C).

\section{5, Comparison of IL-6 and IL-8 production in HGFs after GPR55 mRNA knockdown}

To compare changes in IL-6 and IL-8 production in HGFs with and without GPR55 (non-knockdown and GPR55-knockdown HGFs, respectively), we analyzed IL-6 and IL-8 production at $24 \mathrm{~h}$ after LPS stimulation by ELISA in each cell type. Similar to the control group, the CBD group of non-knockdown HGFs transfected with control siRNA showed little expression of 


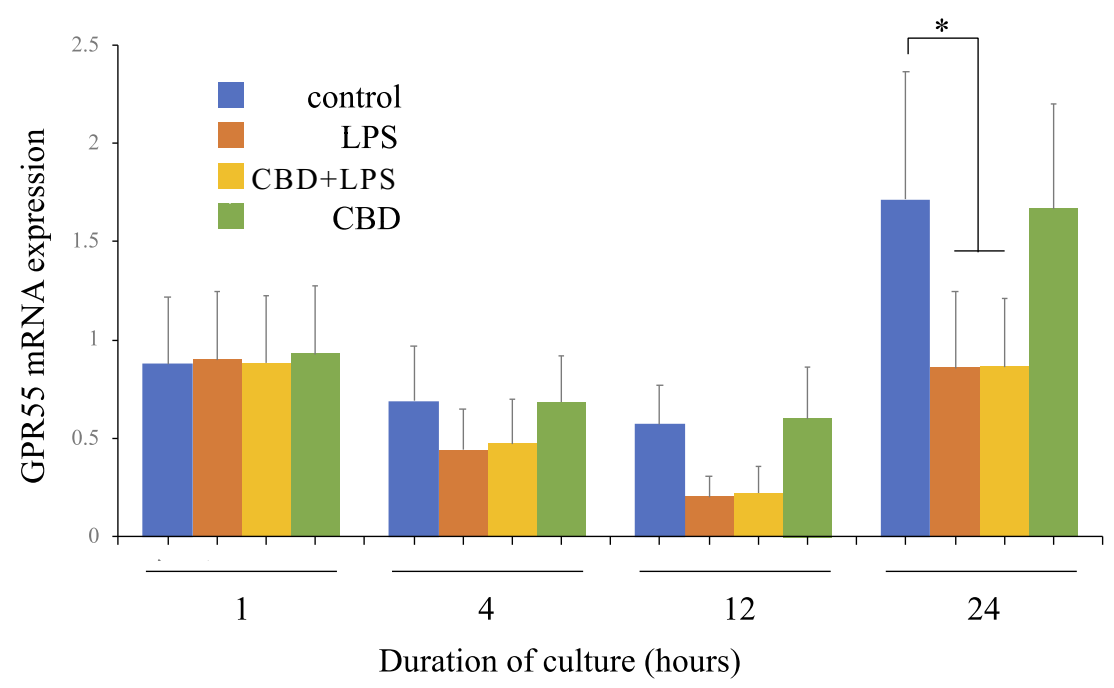

Figure 2 GPR55 mRNA expression in HGFs. Cells were stimulated with $0.1 \mu \mathrm{g}$ / $\mathrm{mL}$ LPS and GPR55 mRNA expression was analyzed by qRT-PCR. Changes in GPR55 gene expression levels were calculated by the $2^{-}$ $\Delta \Delta \mathrm{Ct}$ method with non-stimulated cells set as reference $\left(2^{-\Delta \Delta \mathrm{Ct}}=1\right)$, which were normalized to mRNA expression of housekeeping gene $\beta$-Actin. Data represent mean $\pm \mathrm{SD}$ from five independent experiments. ${ }^{*} p<0.05$, Tukey's comparison test.
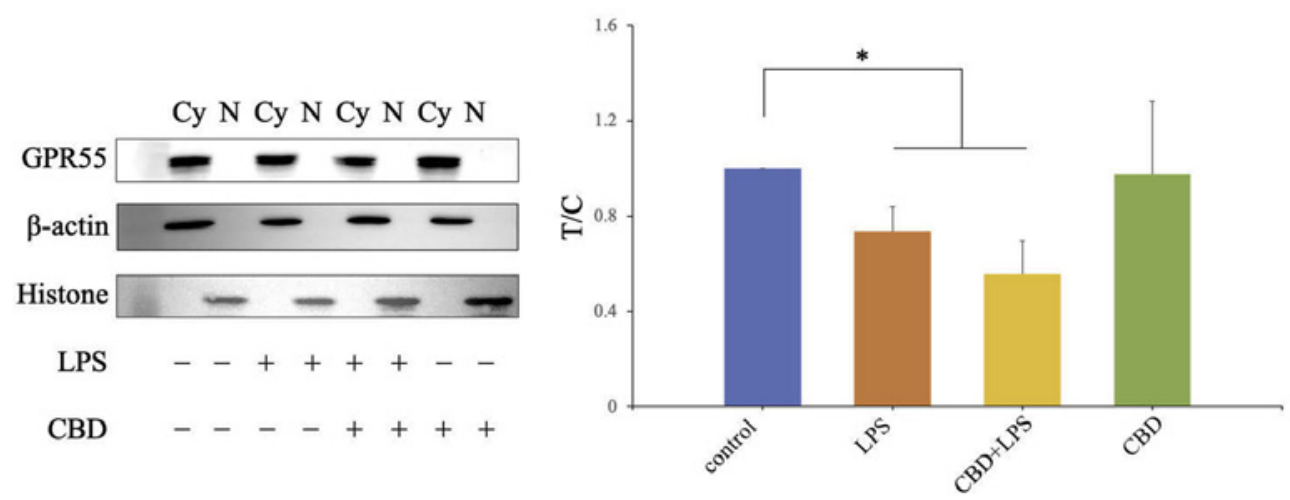

Figure 3 GPR55 protein levels in HGFs were detected by Western blot, with $\beta$-Actin and histone levels included as controls. Histograms show mean $\pm \mathrm{SD}$ of relative quantification, which was normalized to the expression level in control cells. $* x<0.05$, GamesHowell test.

inflammatory cytokines. There was a significant increase in the production of both IL-6 and IL-8 in the LPS and CBD + LPS groups compared to control and the CBD groups $(p<0.05)$ (Figure $5 \mathrm{~A}$ and $\mathrm{C}$ ). However, in comparison between the LPS and CBD + LPS groups, IL-6 production in the CBD + LPS group was significantly suppressed by $28.2 \%(p<0.05)$. Similarly, IL-8 levels were reduced by $22.8 \%$ in the CBD + LPS group compared to the LPS group $(p<0.05)$. Next, we analyzed IL-6 and IL-8 production in GPR 55knockdown HGFs transfected with GPR 55 siRNA.
GPR55 gene expression efficiency was determined by qRT-PCR by comparison with negative control siRNA, and the efficiency was stable and suppressed at 50\%. In GPR55-knockdown HGFs, there was a significant increase in the production of both IL- 6 and IL- 8 in the LPS and CBD + LPS groups compared to the control and $\mathrm{CBD}$ groups $(p<0.05)$. However, no significant change was observed between the LPS and CBD + LPS groups (Figure 5B and D). The production of proinflammatory cytokines in the LPS group was also significantly reduced in GPR55-knockdown HGFs $(p<$ 
A
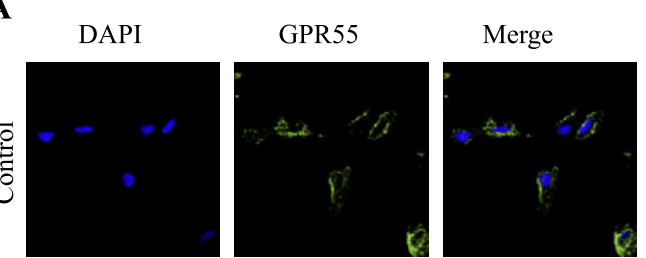

B
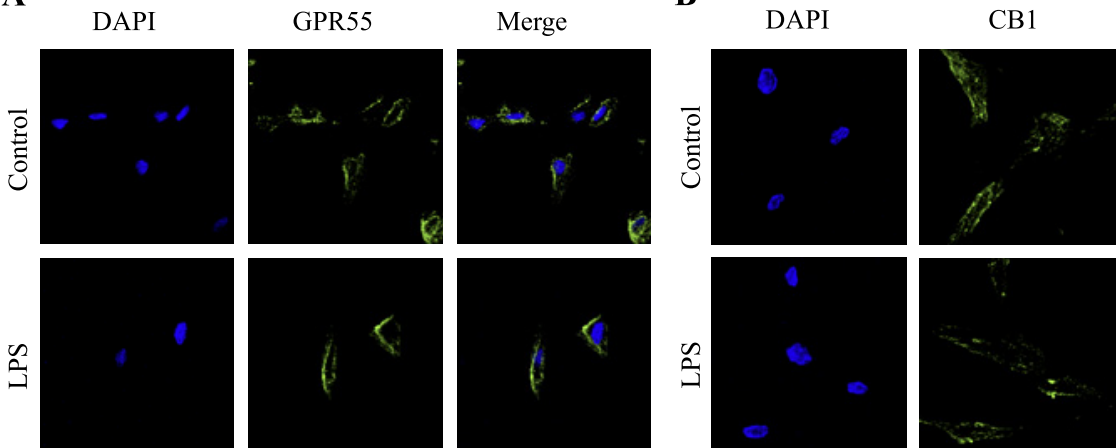

Merge
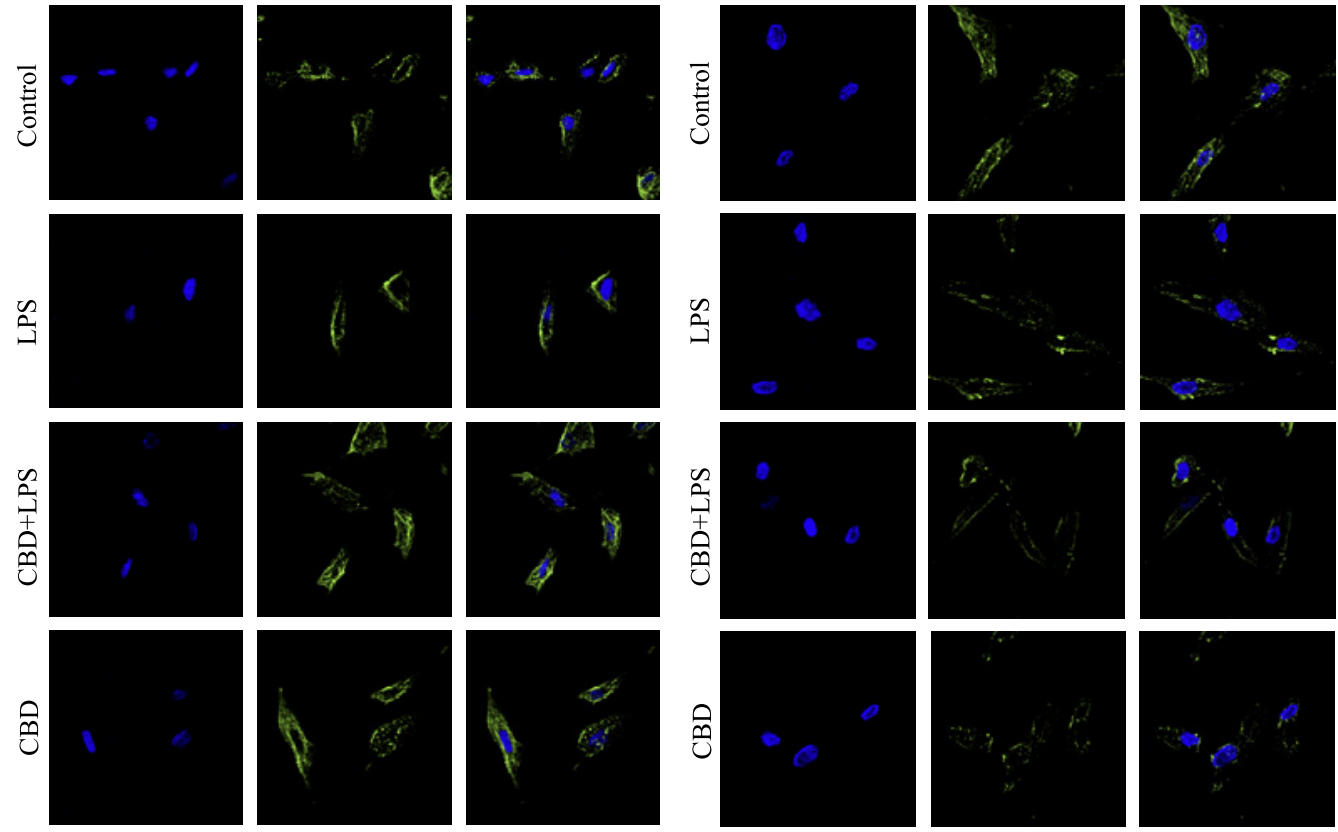

$50 \mu \mathrm{m}$

$50 \mu \mathrm{m}$

C
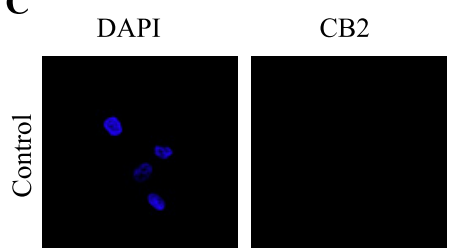

Merge
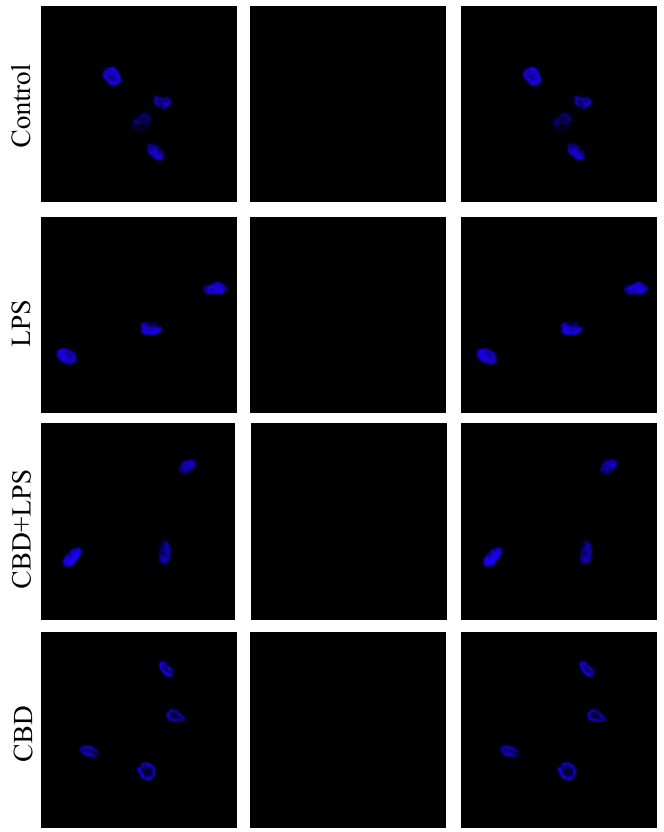

$50 \mu \mathrm{m}$

Figure 4 Localization of GPR55, CB1, and CB2 proteins in HGFs (control group, LPS group, CBD + LPS group, and CBD group) evaluated by fluorescent microscopy. HGFs were pretreated with CBD $(0.5 \mu \mathrm{M})$ for $2 \mathrm{~h}$ before LPS stimulation $(0.1 \mu \mathrm{g} / \mathrm{mL})$ for $24 \mathrm{~h}$ in the CBD $+\mathrm{LPS}$ group. HGFs were then fixed and incubated with anti-GPR55, CB1, or CB2 antibody. (A) Distribution of GPR55 (green) and nucleus (DAPI, blue) in HGFs. (B) Distribution of CB1 (green) and nucleus (DAPI, blue) in HGFs. (C) Distribution of CB2 (green) and nucleus (DAPI, blue) in HGFs. Scale bar, $50 \mu \mathrm{m}$. 
$\mathbf{A}$

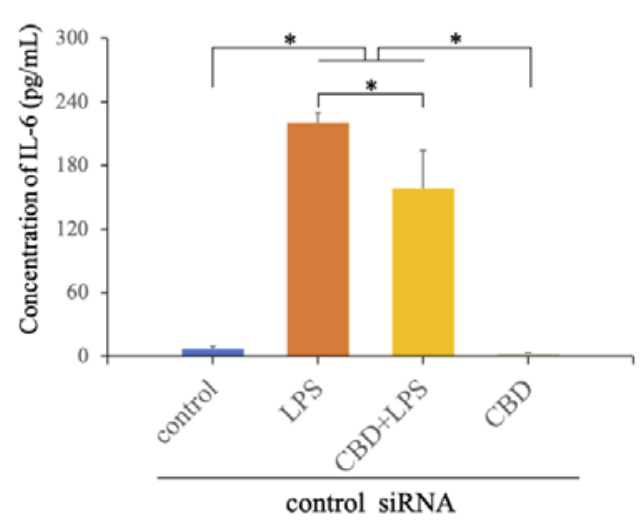

C

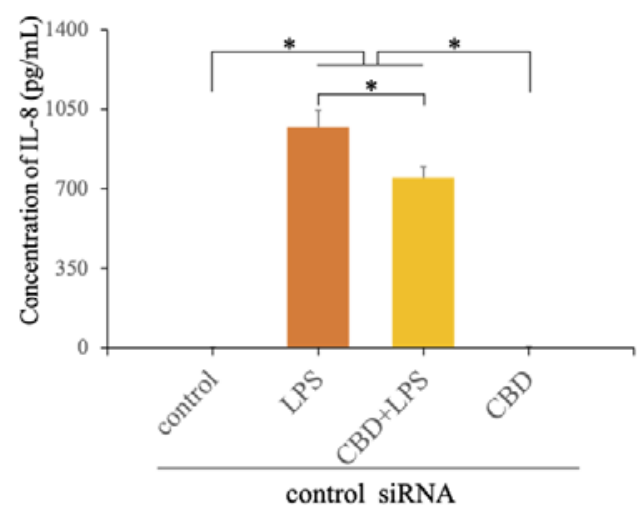

\section{$\mathbf{E}$}
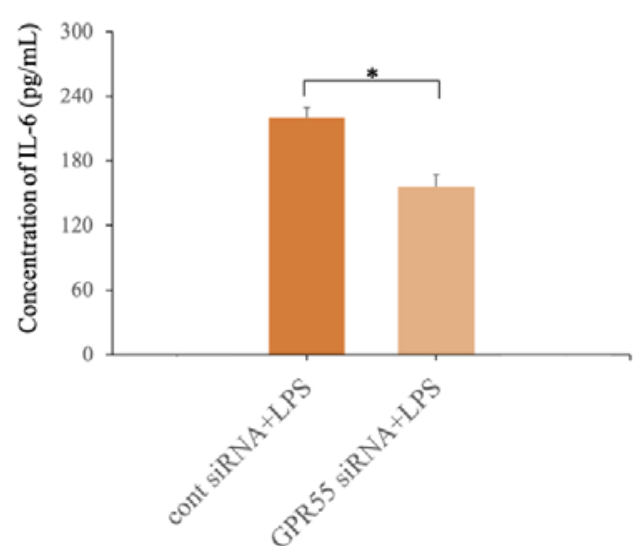

B

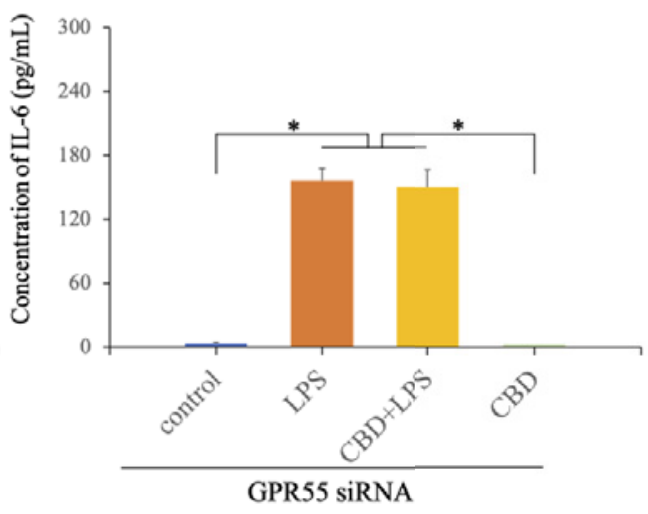

D

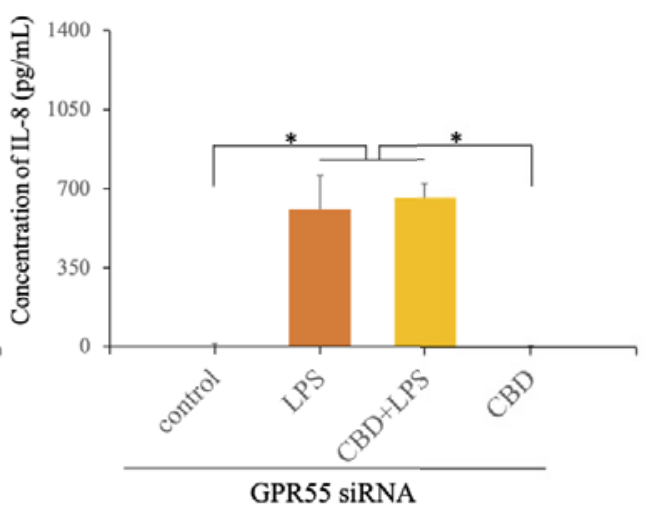

F

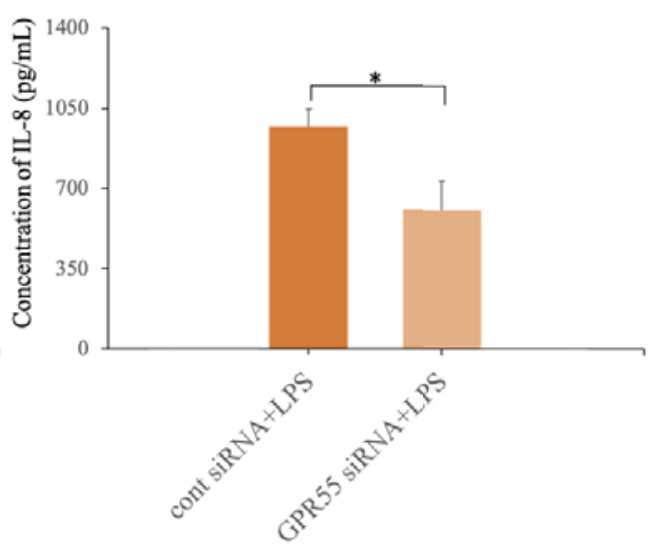

Figure 5 Proinflammatory cytokine secretion was significantly upregulated by LPS stimulation and downregulated by CBD addition in HGFs. HGFs were treated with LPS in the presence or absence of CBD. Interleukin (IL)-6 and IL-8 concentrations were measured by enzyme-linked immunosorbent assay (ELISA). Data are presented as mean \pm SD from five independent experiments. Comparisons were analyzed by ANOVA. * $p<0.05$, Kruskal-Wallis test with Steel-Dwass test. 
0.05) (Figure 5E and F). The significant difference between the LPS and CBD + LPS groups that was observed in non-knockdown HGFs was not observed in GPR55-knockdown HGFs.

\section{Discussion}

Host modulation therapy has been investigated as a means of reducing inflammation in periodontal disease $^{9)}$. We have focused on $\mathrm{CBD}^{14,33)}$ and its receptor, GPR55, as a means to achieve this. GPR55 has been reported to exacerbate inflammation by modulating transcription factors such as NF-kB through its activation 26 ), but the expression and role of GPR55 in periodontal tissue remain unclear. Therefore, in the present study, we first confirmed the expression of GPR 55 in HGFs and observed changes in its expression under LPS-induced inflammation. Then, we examined whether anti-inflammatory effects of CBD were affected by GPR55 knockdown. The results showed that GPR 55 mRNA was homeostatically expressed in HGFs. Although GPR55 mRNA expression in immune tissues and the gastrointestinal tract has been previously reported ${ }^{34}$, it is not clear in periodontal tissues. To our best knowledge, this is the first report about GPR55 mRNA expression in periodontal tissues.

GPR55 mRNA expression showed a time-dependent decreasing trend in the presence of LPS. Lin et al.28) reported that GPR55 mRNA expression is increased in the intestines of rats treated with LPS for $1 \mathrm{~h}$ to induce enteritis. By contrast, it has been reported that GPR55 mRNA expression is reduced in glial cells after $8 \mathrm{~h}$ of LPS stimulation ${ }^{35)}$. The results of the present study were consistent with the latter, but this may be due to the difference in the duration of action of LPS, in which GPR55 tended to increase after a short period of stimulation and then decrease. Evaluation of GPR55 protein expression indicated it is permanently present in the cytoplasmic fraction and was significantly reduced by LPS stimulation. These results are consistent with those for mRNA expression. By contrast, concerning $\mathrm{CB} 1$ and $\mathrm{CB} 2$, little or no expression of either mRNA or protein was observed in HGFs. It has been reported that $\mathrm{CB} 1$ and $\mathrm{CB} 2 \mathrm{mRNA}$ expression is increased in HGFs from patients with chronic periodontitis compared to healthy individuals 36 ). These differences in mRNA and protein expression may be due to the time of exposure to inflammation and the interaction between multispecies cells. Thus, these findings must be investigated by examining the time of exposure to LPS, co-culturing epithelial cells and other periodontal tissue cells with HGFs, and using in vivo models. In the present study, GPR55 expression was reduced upon LPS stimulation. Miller et al. reported that cannabinoid receptors can increase or decrease their number depending on host conditions 377 . For example, decreased CB1 expression in human colorectal cancer 38 ) and increased CB1 and CB2 expression in human prostate cancer have been reported ${ }^{39}$. These findings suggest that the expression of cannabinoid receptors varies according to tissue type, and elucidation of these mechanisms may lead to the development of new treatment methods for periodontal disease.

We also examined anti-inflammatory effects of CBD on HGFs and changes in proinflammatory cytokine production in HGFs by GPR 55 knockdown. Antiinflammatory effects of CBD have also been investigated in other tissues. For example, a study on the application of $\mathrm{CBD}$ in the treatment of rheumatoid arthritis, an inflammatory autoimmune disease, reported that CBD inhibits LPS-stimulated inflammatory cytokines in a murine model of collagen-induced arthritis ${ }^{40)}$. Similarly, periodontal disease, an inflammatory disease, increases the production of proinflammatory cytokines such as IL-6 and IL-8, which are produced from HGFs by LPS stimulation 41). IL-6 is involved in inflammatory cell migration and osteoclast formation ${ }^{42,43)}$. The binding of IL-6 to HGFs promotes the production of tissue degrading enzymes. As a result, the periodontal tissue is destroyed by accelerated degradation of collagen fibers ${ }^{44)}$. In addition, IL-8 similarly promotes periodontal tissue destruction by inducing neutrophil migration and local infiltration ${ }^{45)}$. Thus, inhibition of IL-6 and IL-8 production is one of the most effective ways to prevent the worsening of periodontal disease. Therefore, we hypothesized that preadministration of $\mathrm{CBD}$, which is suggested to be a GPR55 antagonist, could inhibit IL-6 and IL-8 production by GPR55 activation. The results of the present study showed a rapid increase in IL-6 and IL-8 production in the LPS group compared to the control group at $24 \mathrm{~h}$ after stimulation, however, the production was significantly suppressed by the prior addition of CBD. By contrast, in GPR55-knockdown HGFs, the proinflammatory cytokine inhibitory effect of CBD could not be confirmed, because there was no significant difference between the LPS and CBD + LPS groups. It is possible that the action of CBD may be mediated by GPR55. However, IL-6 and IL-8 production in GPR55- 
knockdown HGFs was significantly lower than that in non-knockdown HGFs in the LPS group. In other words, in the knockdown cells, the effect of CBD would not have been observed in the knockdown cells, which would not have reflected the effect of increased proinflammatory cytokine production due to LPS exposure in the first place. It has been reported that activation of GPR55 leads to activation of transcription factors such as NF- $\mathrm{kB}$ through activation of RhoA and phosphorylation of ERK, ultimately leading to an increase in pro-inflammatory cytokines 18). Assuming that CBD acts as an antagonist of GPR55, it may exert its anti-inflammatory effects by inhibiting such signaling. While a study suggested that CBD is a GPR55 antagonist ${ }^{46)}$, some negative results have been reported and are inconclusive ${ }^{26,47)}$. In addition to CB1 and CB2, $\mathrm{CBD}$ is associated with many other receptors, including GPR55, transient receptor potential channels, 5hydroxytryptamine receptors, and peroxisome proliferator-activated receptor 48 ). Therefore, additional studies on other receptors are needed. Furthermore, in the present study, knockdown of GPR 55 mRNA suppressed IL- 6 and IL- 8 production in the LPS group. The fact that HGFs used in this study showed little CB1 and CB2 expression and altered GPR55 expression by LPS suggests that part of the inflammatory effect in HGFs may be mediated by GPR 55. Schicho et al. ${ }^{49)}$ reported that the inflammatory pathway is activated through GPR55 rather than CB1 or CB2 in a murine model of intestinal inflammation that knocked out GPR55. These results correspond with our opinion. It has been reported that HGFs express the TLR gene, which is widely known as a receptor for pathogens ; TLR 4 acts as a receptor for LPS and is involved in the expression of inflammatory cytokines ${ }^{50)}$. Saliba et al. ${ }^{51)}$ reported that GPR55 antagonists act on TLR 4 to inhibit the production of prostaglandin E 2 and other substances in TLR 4expressing rat microglial cells in a model of TLR4induced neuroinflammation by LPS stimulation. GPR 55 may be part of the inflammatory pathway in HGFs as an adjunct in addition to the TLR4-mediated pathway, considering the variation in expression under LPS stimulation. In summary, our results indicate that pretreatment of $\mathrm{CBD}$ inhibits inflammation in periodontal tissues and that GPR55 may be involved in the inflammatory pathway in periodontal tissues. More than $30 \%$ of the drugs currently on the market in Japan target GPCRs, and GPR55, a GPCR, is also considered a major target for drug discovery. Thus, the re- sults suggest that GPR55 may be an effective new target for the treatment of periodontal disease and the possibility that CBD can be a tool for host modulation therapy.

The present study is the first to report the expression of GPR55 in HGFs, and the reduction of GPR55 expression under LPS stimulation. In addition, CBD was found to exert an anti-inflammatory effect by inhibiting the production of pro-inflammatory cytokines induced by LPS in HGFs. Further studies are needed to elucidate the role of GPR55 and the effect of CBD in periodontal tissue, including studies on its association with endogenous cannabinoids, its expression in other cells, the effects of CBD on downstream signaling, and its interaction with other receptors.

\section{Conclusion}

In this study, we investigated GPR55 expression in HGFs, its kinetics under LPS stimulation, and the involvement of GPR55 in the inflammatory response. GPR55 was permanently expressed in HGFs, and its expression tended to decrease upon LPS stimulation. Furthermore, we found that part of the inflammatory response by LPS may be mediated by GPR55 and the anti-inflammatory effect of CBD. These results suggest that GPR55 may be a potential therapeutic target in periodontitis and that $\mathrm{CBD}$ may be an effective therapeutic agent.

\section{Acknowledgement}

The authors extend their deepest gratitude to The Nippon Dental University, School of Life Dentistry, Department of Biochemistry and Department of Periodontology (Tokyo, Japan) for supporting this study.

Conflict of Interest: None.

\section{References}

1) Page RC: Milestones in periodontal research and the remaining critical issues. J Periodontal Res, 34: 331339, 1999.

2) Karin M, Ben-Neriah Y: Phosphorylation Meets Ubiquitination: The Control of NF-kB Activity. Annu Rev Immunol, 18: 621-663, 2000.

3) Ara T, Fujinami Y, Urano H, Hirai K, Hatori T, Miyazawa $\mathrm{H}$ : Protein kinase A enhances 
lipopolysaccharide-induced IL-6, IL-8, and PGE 2 production by human gingival fibroblasts. J Negat Results Biomed, 11: 10, 2012.

4) Ishimi $\mathrm{Y}$, Miyaura $\mathrm{C}$, Jin $\mathrm{CH}$, Akatsu T, Abe E, Nakamura Y, Yamaguchi A, Yoshiki S, Matsuda T, Hirano T: IL- 6 is produced by osteoblasts and induces bone resorption. J Immunol, 145: 3297-3303, 1990.

5) Bickel M: The role of interleukin-8 in inflammation and mechanisms of regulation. J Periodontol, 64: 456-460, 1993.

6) Lindhe J, Westfelt E, Nyman S, Socransky SS, Haffajee $\mathrm{AD}$ : Long-term effect of surgical/non-surgical treatment of periodontal disease. Journal of Clinical Periodontology, 11: 448-458, 1984.

7) Morris AJ, Steele J, White DA: The oral cleanliness and periodontal health of UK adults in 1998. British Dental Journal, 191: 186-192, 2001.

8) Takashiba S, Naruishi K, Murayama Y: Perspective of Cytokine Regulation for Periodontal Treatment : Fibroblast Biology. Journal of Periodontology, 74: 103110, 2003.

9) Philip M Preshaw: Host response modulation in periodontics. Periodontol 2000, 48: 92-110, 2008.

10) Adams IB, Martin R: Cannabis: pharmacology and toxicology in animals and humans. Addiction, 91: 15851614, 1996.

11) Devinsky O, Marsh E, Friedman D, Elizabeth T, Linda L, Sullivan J, Miller I, Flamini R, Wilfong A, Francis F, Matthew W, Nicole T, Patricia B, Judith B, Hedlund J, Rebecca K, Jane M, Srishti N, Nilika SS, Carey AW, Anup P, Cilio Maria RC: Cannabidiol in patients with treatment-resistant epilepsy: an open-label interventional trial. The Lancet Neurology, 15: 270-278, 2016.

12) Darrell GB, Greg G, Giovanni M, Maria FO: The effectiveness of cannabinoids in the management of chronic nonmalignant neuropathic pain: a systematic review. Journal of oral \& facial pain and headache, 29: 7-14, 2015.

13) Simona P, Paola P, Alba D, Chiara L, Maurizio B: The endocannabinoid signaling system in cancer. Trends Pharmacol Sci, 34: 273-282, 2013.

14) Natalya MK, Eitan M, Elad W, Bitya R, Aviva B, Kathryn SS, Sondergaard R, Ana VV Escudero, Saja B, Malka A-N, Silvina F-B, Neashan M, Hanna I, Raphael M, Ralph M, Alon B, Yankel G, Itai B: Cannabidiol, a major non-psychotropic cannabis constituent enhances fracture healing and stimulates lysyl hydroxylase activity in osteoblasts. J Bone Miner Res, 30: 1905-1913, 2015.

15) Mechoulam R, Shvo Y: Hashish. I. The structure of
Cannabidiol. Tetrahedron, 19: 2073-2078, 1963.

16) Simona P, Anna MM, Elena C, Anna L, Roberta R, Gaia C, Mario A, Giorgio F, Maria CP, Donatella F, Chiara L, Maurizio B: Cannabidiol: State of the art and new challenges for therapeutic applications. Pharmacol Ther, 175: 133-150, 2017.

17) Torsten L, Matthias S, Georg P: Joints for joints: cannabinoids in the treatment of rheumatoid arthritis. Curr Opin Rheumatol, 31: 271-278, 2019.

18) Hyewon Y, Juan Z, Christian L: GPR55 - a putative “type 3" cannabinoid receptor in inflammation. J Basic Clin Pharmacol, 27: 297-302, 2016.

19) Kozela E, Pietr M, Juknat A, Rimmerman N, Levy R, Vogel Z: Cannabinoids $\Delta$ 9-tetrahydrocannabinol and cannabidiol differentially inhibit the lipopolysaccharide-activated NF- $\mathrm{KB}$ and interferon- $\beta$ / STAT proinflammatory pathways in BV-2 microglial cells. J Biol Chem, 285: 1616-1626, 2010.

20) Pertwee RG: Pharmacology of cannabinoid CB1 and CB2 receptors. Pharmacol Ther, 74: 129-180, 1997.

21) Croxford JL: Therapeutic potential of cannabinoids in CNS disease. CNS Drugs, 17: 179-202, 2003.

22) Munro S, Thoma KL, Abu-Shaar M: Molecular characterization of a peripheral receptor for cannabinoids. Nature, 365: 61-65, 1993.

23) Sawzdargo M, Nguyen T, Lee DK, Lynch KR, Cheng R, Heng HH, George SR, O'Dowd BF: Identification and cloning of three novel human G protein-coupled receptor genes GPR52, 世GPR53 and GPR55: GPR55 is extensively expressed in human brain. Brain Res Mol Brain Res, 64: 193-198, 1999.

24) Lesley AF, Roelofs AJ, Sharon A-G, Luisa M, Daniel GS, Andrew JI, Michael J Rm, Ann MR, Ruth AR: A role for L- $\alpha$-lysophosphatidylinositol and GPR55 in the modulation of migration, orientation and polarization of human breast cancer cells. Br J Pharmacol, 160: 762$771,2010$.

25) Whyte LS, Ryberg E, Natalie AS, Ridge SA, Mackie K, Greasley PJ, Ross AR, Rogers MJ: The putative cannabinoid receptor GPR55 affects osteoclast function in vitro and bone mass in vivo. Proc Natl Acad Sci U S A, 106: 16511-16516, 2009.

26) Henstridge CM, Balenga NA, Schröder R, Kargl JK, Platzer W, Martini L, Arthur S, Penman J, Whistler Jennifer L, Kostenis E, Waldhoer M, Irving AJ: GPR55 ligands promote receptor coupling to multiple signalling pathways. Br J Pharmacol, 160: 604-614, 2010.

27) Oka S, Kimura S, Toshida T, Ota R, Yamashita A, Sugiura T: Lysophosphatidylinositol induces rapid phosphorylation of p 38 mitogen-activated protein 
kinase and activating transcription factor 2 in HEK293 cells expressing GPR55 and IM-9 lymphoblastoid cells. J Biochem, 147: 671-678, 2010.

28) Lin XH, Yuece B, Li YY, Feng YJ, YU LY, Li K, Li NY, Storr M: A novel CB receptor GPR55 and its ligands are involved in regulation of gut movement in rodents. Neurogastroenterol Motil, 23: 862-871, 2011.

29) Chiurchiù V, Lanuti M, Bardi MD, Battistini L, Maccarrone M: The differential characterization of GPR55 receptor in human peripheral blood reveals a distinctive expression in monocytes and NK cells and a proinflammatory role in these innate cells. Int Immunol, 27: 153-160, 2015.

30) Liu C, Qi X, Alhabeil J, Lu H, Zhou Z: Activation of cannabinoid receptors promote periodontal cell adhesion and migration. J Clin Periodontol, 46: 1264-1272, 2019.

31) Ossola CA, Surkin PN, Mohn CE, Elverdin JC, Fernández-Solari J: Anti-Inflammatory and Osteoprotective Effects of Cannabinoid-2 Receptor Agonist HU308 in a Rat Model of Lipopolysaccharide-Induced Periodontitis. J Periodontol, 87: 725-734, 2016.

32) Napimoga MH, Benatti BB, Lima FO, Alves PM, Campos AC, Pena-dos-Santos DR, Severino FP, Cunha FQ, Guimarães FS: Cannabidiol decreases bone resorption by inhibiting RANK/RANKL expression and proinflammatory cytokines during experimental periodontitis in rats. Int Immunopharmacol, 9: 216-222, 2009.

33) Burstein S: Cannabidiol (CBD) and its analogs: A review of their effects on inflammation. Bioorg Med Chem, 23: 1377-1385, 2015.

34) Ryberg E, Larsson N, Sjögren S, Hjorth S, Hermansson NO, Leonova J, Elebring T, Nilsson K, Drmota T, Greasley PJ: The orphan receptor GPR55 is a novel cannabinoid receptor. Br J Pharmacol, 152: 1092-1101, 2007.

35) Pietr M, Kozela E, Levy R, Rimmerman N, Lin YH, Stella N, Vogel Z, Juknat A: Differential changes in GPR55 during microglial cell activation. FEBS Lett, 583: 2071-2076, 2009.

36) Kozono S, Matsuyama T, Biwasa KK, Kawahara K, Nakajima Y, Yoshimoto T, Yonamine Y, Kadomatsu H, Tancharoen S, Hashiguchi T, Noguchi K, Maruyama I: Involvement of the endocannabinoid system in periodontal healing. Biochem Biophys Res Commun, 394: 928-933, 2010.

37) Miller LK, Devi LA: The highs and lows of cannabinoid receptor expression in disease: Mechanisms and their therapeutic implications. Pharmacol Rev, 63: 461-
470, 2011.

38) Wang D, Wang H, Ning W, Backlund MG, Dey SK, DuBois RN: Loss of cannabinoid receptor 1 accelerates intestinal tumor growth. Cancer Res, 68: 6468-6476, 2008.

39) Sarfaraz S, Afaq F, Adhami VM, Malik A, Mukhtar H: Cannabinoid receptor agonist-induced apoptosis of human prostate cancer cells LNCaP proceeds through sustained activation of ERK1/2 leading to G 1 cell cycle arrest. J Biol Chem, 281: 39480-39491, 2006.

40) Malfait AM, Gallily R, Sumariwalla PF, Malik AS, Andreakos E, Mechoulam R, Feldmann M: The nonpsychoactive cannabis constituent cannabidiol is an oral anti-arthritic therapeutic in murine collagen-induced arthritis. Proc Natl Acad Sci U S A, 97: 9561-9566, 2000.

41) Uchihashi T, Kurihara S, Ara T, Kurata K, Wang PL, Uematsu T, Imamura Y, Furusawa K: Human gingival fibroblasts are critical in sustaining inflammation in periodontal disease. J Periodontal Res, 44: 21-27, 2009.

42) Graves D: Cytokines That Promote Periodontal Tissue Destruction. J Periodontol, 79: 1585-1591, 2008.

43) Fonseca JE, Santos MJ, Canhão H, Choy E : Interleukin- 6 as a key player in systemic inflammation and joint destruction. Autoimmun Rev, 8: 538-542, 2009.

44) Naruishi K, Takashiba S, Nishimura F, Chou HH, Arai $\mathrm{H}$, Yamada H, Murayama Y: Impairment of gingival fibroblast adherence by IL-6/sIL-6R. J Dent Res, 80: 1421-1424, 2001.

45) Fredriksson M, Bergström K, Åsman B: IL-8 and TNF- $\alpha$ from peripheral neutrophils and acute-phase proteins in periodontitis. J Clin Periodontol, 29: 123-128, 2002.

46) Johns DG, Behm DG, Walker DJ, Ao Z, Shapland EM, Daniels DA, Riddick M, Dowell S, Staton PC, Green P, Shabon U, Bao W, Aiyar N, Yue TL, Brown AJ, Morrison AD, Douglas SA: The novel endocannabinoid receptor GPR55 is activated by atypical cannabinoids but does not mediate their vasodilator effects. $\mathrm{Br} \mathrm{J}$ Pharmacol, 152: 825-831, 2007.

47) Oka S, Toshida T, Maruyama K, Nakajima K, Yamashita A, Sugiura T: 2-Arachidonoyl-sn-glycero-3phosphoinositol: A possible natural ligand for GPR55. J Biochem, 145: 13-20, 2009.

48) Pertwee R: Handbook of Cannabis, Oxford University Press, 2015.

49) Schicho R, Storr M: A potential role for GPR55 in gastrointestinal functions. Curr Opin Pharmacol, 12: 653658, 2012.

50) Wang PL, Oido-Mori M, Fujii T, Kowashi Y, Kikuchi 
M, Suetsugu Y, Tanaka J, Azuma Y, Shinohara M, Ohura K: Heterogeneous expression of Toll-like receptor 4 and downregulation of Toll-like receptor 4 expression on human gingival fibroblasts by Porphyromonas gingivalis lipopolysaccharide. Biochem Biophysl Res Commun, 288: 863-867, 2001.
51) Saliba SW, Jauch H, Gargouri B, Keil A, Hurrle T, Volz N, Mohr F, Mario VDS, Bräse S, Fiebich BL: Antineuroinflammatory effects of GPR55 antagonists in LPS-activated primary microglial cells. J Neuroinflammation, 15: 322, 2018.

\title{
ヒト歯肉線維芽細胞におけるカンナビノイド受容体 GPR55の発現と GPR55 を介したカンナビジオールの抗炎症作用の検討
}

\author{
三 代 紗 季, 五十嵐（武内）寛子，沼 部 幸 博 \\ 日本歯科大学生命歯学部歯周病学講座 \\ (受付日：2020 年 11 月 20 日 受理日：2021 年 1 月 5 日)
}

\begin{abstract}
要旨：大麻に含まれるカンナビジオール (CBD) は抗炎症作用を有し，その受容体とされる G-protein coupled receptor 55（GPR55）は炎症制御との関連が示唆されている。本論文ではヒト歯肉線維芽細胞 (HGFs)に扔けるGPR55 の発現状態と,GPR55を介したCBD の抗炎症作用とを検討した。HGFs を Control 群, LPS 群, CBD 処理後 LPS 刺激群 (CBD + LPS 群), CBD 群に分け受容体の発現および局在を確 認した。GPR55 ノックダウンの有無により, 培養上清中の Interleukin (IL)-6 および IL-8 タンパク質産 生量を比較した。GPR55 の発現量は LPS 群拉よびCBD + LPS 群で有意に減少し $(\mathrm{p}<0.05)$, タンパク質 の局在は全群の HGFs の細胞質内にびまん性に認められた。また，非ノックダウン HGFs では LPS 群と

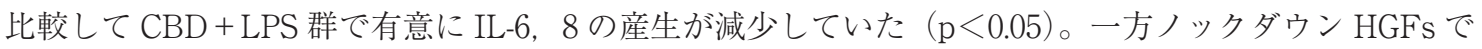
は， control 群と比較して LPS 群と CBD + LPS 群で有意に IL-6，8 の産生が増加していたが $(\mathrm{p}<0.05)$ ， 両群間に有意な差はなかった。本研究では HGFs における GPR55 の恒常的発現と, 炎症下での発現減少 傾向を確認し，CBD による抗炎症作用の一部が GPR55 年する可能性が示唆された。
\end{abstract}

日本歯周病学会会誌（日歯周誌）63（1）：11-23，2021

キーワード：カンナビジオール，G タンパク質共役型受容体 GPR55，抗炎症作用，サイトカイン， ヒ卜歯肉線維芽細胞

\author{
連絡先：五十嵐（武内）寛子 \\ 干102-8159 東京都千代田区富士見 1-9-20 \\ 日本歯科大学生命歯学部歯周病学講座 \\ E-mail : hiroko.p0324@gmail.com
}

